Article

\title{
Drought Monitoring in Chaharmahl-Bakhtiyari Province in Iran
}

\author{
Hamid Mohammadi ${ }^{1}$, Mojgan Abasi ${ }^{2}$, Javad Bazrafshan ${ }^{3}$ \\ ${ }^{1}$ Departamento de Florestas, Universidade de Shahrekord, Shahrekord, Irã. \\ ${ }^{2}$ Faculdade de Recursos Naturais, Universidade de Shahrekord, Shahrekord, Irã. \\ ${ }^{3}$ Faculdade de Agricultura, Universidade de Teerã, Teerã, Irã.
}

Received: September 7, 2016 - Accepted: May 12, 2017

\begin{abstract}
The monitoring of drought is the most important factor in water resources management. This study focuses on evaluation of the drought characteristics such as intensity, frequency and duration drought using Standardized Precipitation Index (SPI) in different time scales such as: SPI1, SPI3 months, during 1980-2012. The results show that selection of different time scales can be based on management goals and kind of drought. The results of the drought occurrence frequency showed that, with increase of length of time scales, drought duration will increase and maximum frequency was at the normal level and there is no particular procedure in different time scales. Furthermore, Drought patterns maps showed that the northern and central parts of study area had experienced these recent droughts more than other places, and these place have potential to destroy the lands. So, by identification of sensitivity regions can be take appropriate management to prevent damage resulting of drought.
\end{abstract}

Keywords: drought monitoring, different time scales, drought pattern, drought duration, Standardized Precipitation Index (SPI).

\section{Monitoramento da Seca na Província de Chaharmahl-Bakhtiyari no Irã}

\begin{abstract}
Resumo
O monitoramento da seca é o fator mais importante na gestão de recursos hídricos. Este estudo centra-se na avaliação das características da seca, como intensidade, frequência e duração da seca, utilizando o Índice Padronizado de Precipitação (SPI) em diferentes escalas de tempo, tais como: SPI1, SPI3 (mensal), durante 1980-2012. Os resultados mostram que a seleção de diferentes escalas de tempo pode ser baseada em gerenciamento de metas e tipos de seca. Os resultados com base na frequência de ocorrência de seca mostraram que, com o aumento do período de tempo analisado, aumentou a duração da seca e a frequência máxima além do nível normal e não há nenhum procedimento específico em diferentes escalas de tempo. Além disso, os mapas de padrões de seca mostraram que as partes do norte e central da área de estudo experimentaram secas recentes mais do que outras regiões, tento esses locais grande potencial para catástrofes resultantes da seca. Assim, através da identificação de regiões mais sensíveis a esta ação climática, pode-se definir uma gestão apropriada para evitar grandes danos.
\end{abstract}

Palavras-chave: monitoramento da seca, diferentes escalas de tempo, padrão de seca, duração da seca, Índice de Precipitação Padronizado (SPI).

\section{Introduction}

Drought is a natural phenomenon which is caused to the lack of precipitation over a time period. Also, it affect both surface water and groundwater resources, so that, it lead to reduced water supply, declined water quality, crop failure and disturbed habitats (Riebsame et al., 1991).
Drought by itself is not a disaster. Whether it becomes a disaster depends on its impact on local people, economies and the environment (WMO, 2006).

Totally, Drought is defined as a temporary meteorological event whereas the lack of precipitation over an extended period of time compared with some long term average condition. Considering, slowly development of

Autor de correspondência: Hamid Mohammadi, h.mohammadi.n@gmail.com. 
drought, the detection of drought is difficult in any single region.

In addition, regular drought monitoring system provide early warning of drought's onset, persistence, severity and spatial extent in establishing a national drought policy or strategy (Hayes et al., 2011). So, a number of indices have been proposed for drought analysis (e.g. Palmer Drought Severity Index, PDSI; Palmer, 1965), Standardized Precipitation Index (SPI; Mckee et al., 1993), Effective Drought Index (EDI; Byun and Wilhite, 1999), Reconnaissance Drought Index (RDI; Tsakiris et al., 2007), the China-Z index (CZI), is used by the National Metrological Center of China (Wu et al., 2001)

The SPI is obtained by transforming the cumulative probability of precipitation using the inverse of standard normal distribution (Hao and Aghakhochak, 2013) various indices have different operation in terms of drought onset, persistence and termination.

Totally, Drought can be classified into meteorological, agricultural and hydrological and socio-economical drought (Wilhite and Glantz, 1985). Meteorological drought when appears that deficit in precipitation be occurred, with keeping to drought deficit in soil moisture be occurred (agricultural drought). Mo (2011) mentioned that the onset of meteorological drought occurred earlier than agricultural drought. So, precipitation deficit is a suitable variable to detection the drought onset. Drought monitoring based on one single index to indicate the complexity of drought conditions and impact is one of the important limitations to drought monitoring (Wilhite, 2005). While, The SPI can be used to assign the intensity of drought or wet year phenomenon in any time scale for anywhere having rain gauging stations.
Many studies on different aspect of drought especially drought monitoring were carried out in different parts of the world and Iran. Morid et al. (2006), comprised the seven meteorological indices for drought monitoring in Iran, the results showed that The SPI and EDI were able to detect the onset of drought, so it was recommended for operational drought monitoring. Also, Jain et al. (2015), evaluated the drought indices for appraisal of drought characteristic. Hao and Aghakochak (2013), studied a Nonparametric Multivariate Multi-Index Drought Monitoring Framework, namely, the multivariate standardized drought index (MSDI), for describing droughts based on the states of precipitation and soil moisture.

Iran, with an area of 164 milion hectares is located in arid and semi arid sphere in the world. In drought incident in 1999, Management and Planning Organization estimated the costs of such impacts to be ( $\$ 1.25$ Billion) of which more than 80 percent constituted damages of crop, ranges and livestock. According to the latest estimate, total damages to national economy resulting from drought during 1998-2001 were over (\$7.5 billion) (Garshasbi, 2016). So, attention to drought monitoring is importanat for risk management.

This study focuses on drought monitoring by SPI1, API3, SPI6, SPI9, SPI12, SPI18, SPI24, and SPI48 months in the Chaharmahal-bakhtiyari province of Iran.

\section{Data and Method}

\subsection{Study area}

Chahrmahal-Bakhtiyri province is located in the southwest part of Iran, Fig. 1. The province has a total area of $16421 \mathrm{~km}^{2}$. Precipitation varied in different part of study

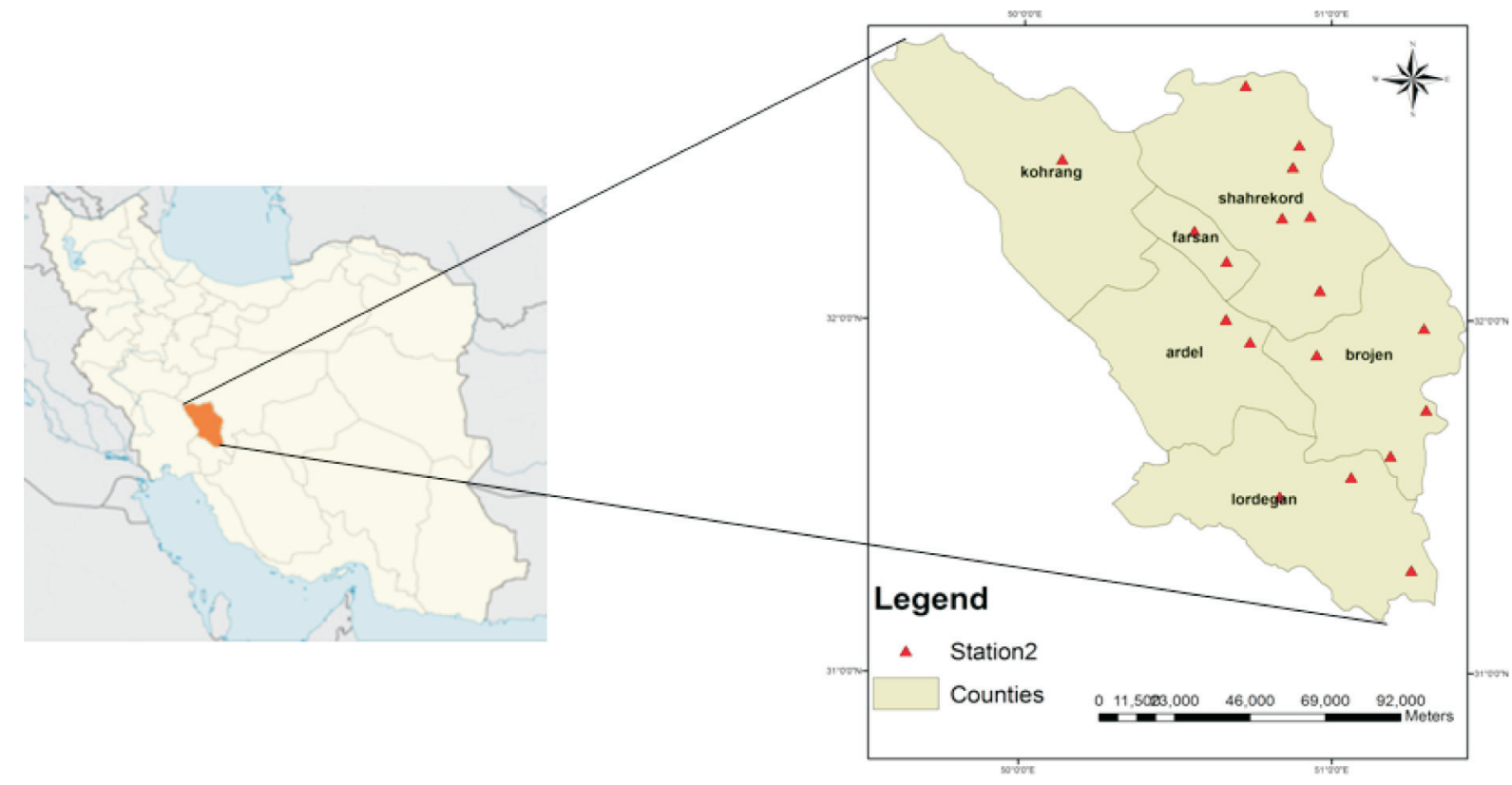

Figure 1 - Location of the Chahrmahl-Bakhtiyari province and meterological station. 
area, but mean annual precipitation is $560 \mathrm{~mm}$ (Fig. 2). The average elevation of the province is about $2066 \mathrm{~m}$ above mean sea level (msl).

In this paper, SPI indices in different scales were compared and evaluated using the average monthly and annual precipitation data of 15 stations. The record length is from 1980 to 2012. Missing data gaps were patched using regression equation by nearest suitable station data. The locations of the selected stations and their detailed are shown in Fig. 1 and Table 1, respectively.

\subsection{Standardized precipitation index}

The SPI was calculated by McKee et al. (1993), to quantify the precipitation deficit for multiple time scales. The time scale of the SPI index is flexible, so that SPI can be computed with different time steps $(1,3,6,12,24,48$ months). The SPI can be used for monitoring both dry and wet years. But, the data record length of precipitation should be set at least 30 years (Wu et al., 2001). Totally, the objective choice on the best time step is depend on the kind of drought analysis. In this paper, the SPI over time periods of 1, 3, 6, 12, 18, 24 and 48 month time scales were applied the based on the long-term precipitation record for selected stations.

Short-term duration (1-month) might be important to meteorological drought, medium-term duration (3 month) is important to agricultural interests, while the long term

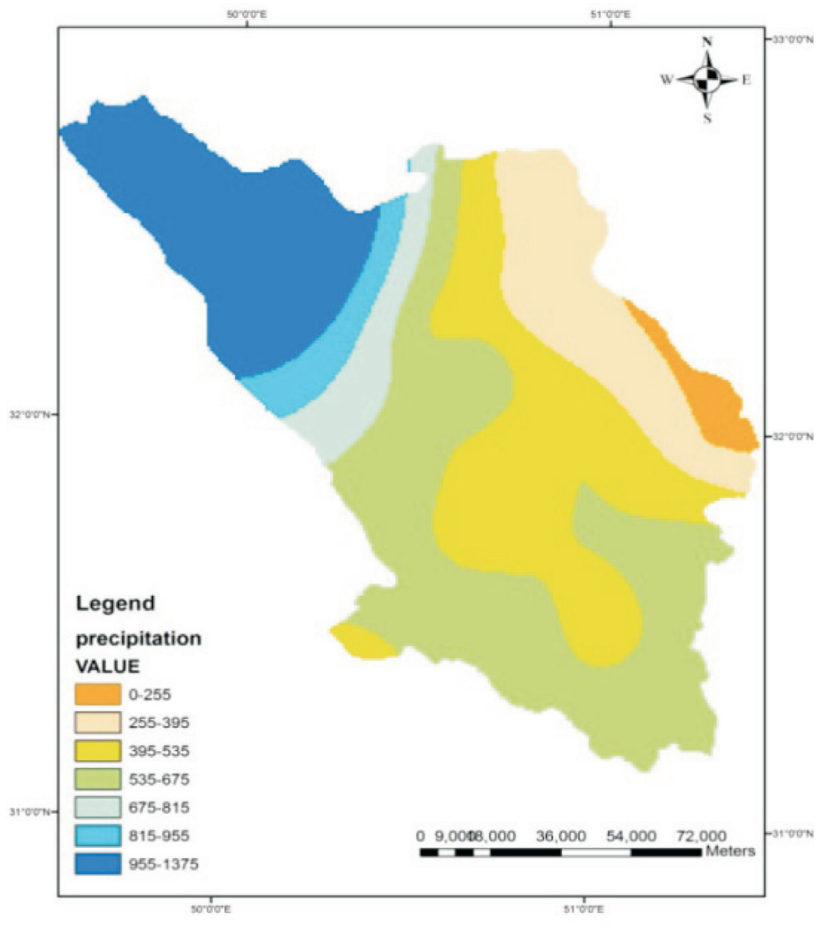

Figure 2 - Mean of precipitation during 1980-2012.

duration (6-12 month) covers water supply management interests. Table 2 shows the classes SPI index.

Table 1 - Mean monthly, annual rainfall (mm) of stations in study area.

\begin{tabular}{|c|c|c|c|c|c|c|c|c|c|c|c|c|c|}
\hline \multirow[b]{2}{*}{ Station } & \multicolumn{12}{|c|}{ Mean monthly Rainfall of various districts (mm) } & \multirow{2}{*}{$\begin{array}{c}\text { Mean annual } \\
(\mathrm{mm})\end{array}$} \\
\hline & Jan & Feb & Mar & Apr & May & Jun & Jul & Aug & Sep & Oct & Nov & Dec & \\
\hline ShahrKord & 57.9 & 50.5 & 57.7 & 40.1 & 13.1 & 0.90 & 1.88 & 0.38 & 0.23 & 7.10 & 37.06 & 57.38 & 324.22 \\
\hline Emam chaie & 92.2 & 96.9 & 106.3 & 72.6 & 24.6 & 1.87 & 1.95 & 0.96 & 0.20 & 12.7 & 58.8 & 94.04 & 563.20 \\
\hline Dezak & 71.2 & 67.1 & 83.9 & 52.9 & 16.5 & 0.99 & 1.5 & 0.5 & 0.3 & 9.52 & 55.6 & 80.98 & 441.31 \\
\hline zamankhan & 55.3 & 51.1 & 55.7 & 42.3 & 16.8 & 0.84 & 1.08 & 0.84 & 0.46 & 8.63 & 41.0 & 54.78 & 329.04 \\
\hline Ardal & 100.7 & 90.9 & 91.0 & 59.6 & 12.2 & 0.68 & 0.75 & 0.29 & 1.34 & 9.5 & 72.8 & 111.3 & 554.74 \\
\hline Boroojen & 41.9 & 36.8 & 48.3 & 31.4 & 7.9 & 1.3 & 0.62 & 0.34 & 0.63 & 5.19 & 31.7 & 48.75 & 254.93 \\
\hline Kohrang & 217.1 & 230.4 & 268.6 & 155.2 & 44.5 & 1.33 & 0.87 & 1.02 & 1.90 & 43.8 & 180.2 & 230.8 & 1375.7 \\
\hline Farokhshar & 51.9 & 44.8 & 45.3 & 38.89 & 7.94 & 1.14 & 0.34 & 0.26 & 0.55 & 5.31 & 43.99 & 54.51 & 294.85 \\
\hline Farsan & 81.7 & 86.4 & 85.6 & 58.48 & 13.9 & 0.86 & 0.14 & 0.86 & 0.89 & 9.87 & 78.18 & 87.38 & 497.62 \\
\hline Jonaghan & 102 & 112 & 114.5 & 78.27 & 21.5 & 1.29 & 0.24 & 0.07 & 1.34 & 10.78 & 86.18 & 98.30 & 626.16 \\
\hline Khanmirza & 108.5 & 83.9 & 82.6 & 49.31 & 4.86 & 0.12 & 0.14 & 0.35 & 1.21 & 5.28 & 57.24 & 104.5 & 497.97 \\
\hline Lordegan & 121.8 & 90.3 & 85.3 & 61.79 & 7.96 & 0.43 & 1.00 & 0.28 & 1.07 & 6.32 & 65.28 & 117.3 & 558.89 \\
\hline Mal Khalifeh & 122.1 & 93.5 & 99.6 & 59.73 & 9.53 & 0.04 & 0.77 & 0.17 & 0.07 & 5.62 & 74.57 & 126.8 & 592.02 \\
\hline Naghan & 66.5 & 69.5 & 86.6 & 67.27 & 17.4 & 1.72 & 2.07 & 0.72 & 1.11 & 14.19 & 70.46 & 72.09 & 469.55 \\
\hline Oergan & 82.1 & 79.2 & 92.6 & 67.60 & 23.7 & 1.43 & 5.80 & 1.01 & 0.60 & 12.06 & 68.88 & 101.4 & 537.67 \\
\hline Saman & 51.7 & 52.8 & 61.5 & 41.46 & 12.3 & 1.43 & 0.12 & 1.16 & 0.71 & 6.2 & 43.54 & 52.26 & 333.25 \\
\hline Yancheshme & 56.4 & 56.2 & 66.5 & 43.15 & 20.4 & 1.64 & 1.59 & 0.62 & 0.40 & 8.97 & 39.39 & 57.53 & 352.77 \\
\hline ben & 68.1 & 56.2 & 56.5 & 37.14 & 10.9 & 2.92 & 0.25 & 0.62 & 0.24 & 4.60 & 39.15 & 57.18 & 333.78 \\
\hline
\end{tabular}


Table 2 - Dry and wet categories of various drought indices based on index value.

\begin{tabular}{lccc}
\hline Values & SPI & Class & Symbol \\
\hline 3 & $\geq 2$ & Extremely wet & EW \\
2 & 1.5 to 1.99 & Severely wet & SW \\
1 & 1 to 1.49 & Moderately wet & MW \\
0 & -0.99 to 0.99 & Normal & $\mathrm{N}$ \\
-1 & -1 to -1.49 & Moderately dry & MD \\
-2 & -1.5 to -1.99 & Very dry & VD \\
-3 & $\leq-2$ & Extremely dry & ED \\
\hline
\end{tabular}

When the SPI value is continuously negative and reaching a value of -1.0 or less, drought has occurred (McKee et al., 1993; Paulo and Pereira, 2006). This index is the transformation of the precipitation time series into a standardized normal distribution. It was calculated by McKee et al. (1993), Wu et al. (2007). SPI index, as one of the most important meteorological drought index, has been used in the world (Guttman, 1999; Pandey et al., 2008; Roudier and Mahe, 2010; etc.). SPI is an index based on the probability of rainfall for various timescale. It can be evaluated the severity of drought, so that, time scales reflect the impact of the drought on the water resources availability (WMO, 2006).

\section{Results and Discussion}

The initiation and end of drought in different time scales were compared for Shahrekord station in period 1980-2012 (Shown in Table 3). The results showed that, from The 2000 to 2012 extremely drought have recorded for SPI1, on April 2000 and 2001, March 2008 December 2011 and January 2012. Also, dry condition was recorded on October, 2000 and March 2008 for six, nine month time scales. All time scales showed the onset of the drought during the same year, While the month of drought onset were different for various time scales, So that, SPI1 (Mar) indicated the onset of drought earlier than SPI3 (Apr), SPI6 (Jul) and SPI9 (Oct). It is worth mentioning that the SPI at one time scale reflects shortterm precipitation patterns. While the SP18, SPI12,
SPI24 and SPI48 responds more slowly to changes in precipitation and gives longer duration of drought compared to SPI1, SPI3. So with consider to kind of drought, appropriate time scale should be selected for evaluation and monitoring of drought.

Also, percentage of drought frequency in different time scales SPI are shown in Fig. 3. It obvious, the frequency of occurrence of the moderately drought is more than extremely and severity dry condition (Tab 4 and Fig. 3). Also, by analyzing the results of drought, it is clear that with increase of length of time scales, drought duration will increase. So that the high value of extremely and moderately dry were observed for SPI with 6 and 9 month time scales.

Table 4, Summarizes the percentage of the relative frequencies, by comparing the frequency of SPI in different time scales, during 32 years in Shahrekord, Dezak, Emam chaie and Pole zamankhan satations, it become clear that maximum frequency is at the normal level and there is no particular procedure in different time scales (Table 4).

The maximum frequency is observed at Pole zamankhan station with $85.3 \%$ at in 24 months time scale, in a normal class. The most frequency of extremely drought was observed in Dezak station (4.5\%) where is located in the eastern parts of study area.

The oak decline is one of the most serious problem in the Zagros forest that is leads to destruction, the southwest parts of study areas suffer from this problem, including: Helen, Saveh, Barez and Shahsavar.

Figures 4 and 5 shows relative frequency of SPI in time scale one month, during the 30 years period in two parts. (1983-1998) and (1998-2013). As shown in Fig. 4, the frequency of extremely and severity drought occurrences on April are more than January duration 1998-2013. It is also observed that drought frequency on January increased in the second half of the period compared to the first period.

Figure 5 shows the frequency of drought occurrence in study area and forest under oak decline in ChaharmalBakhtiyari province. As shown in Fig. 5, the central and southwest parts are more sensitivity in terms of vulnerability, which is according with forest under oak decline. Because the droughts happened approximately 5-15 times in

Table 3 - Comparison of initiation and end of drought events with the SPI obtained in different time scales.

\begin{tabular}{|c|c|c|c|c|c|c|c|c|}
\hline & Initiation & End & Initiation & End & Initiation & End & Initiation & End \\
\hline SPI48 & - & - & 2001(Apr) & 2001(Nov) & 2002(Mar) & 2002(Apr) & - & - \\
\hline SPI24 & 2000(Mar) & 2000 (Nov) & 2001(Feb) & 2001 (Oct) & - & - & - & - \\
\hline SPI18 & 2000(Apr) & $2000($ Sep$)$ & 2001(Apr) & 2001(Aug) & 2008 (Oct) & 2008(Dec) & 2009(Jan) & 2009(Mar) \\
\hline SPI9 & 2000 (Oct) & 2000 (Nov) & - & - & 2008(Mar) & 2008 (Oct) & - & - \\
\hline SPI6 & $2000(\mathrm{Jul})$ & $2000($ Oct $)$ & - & - & 2008(Mar) & $2008(\mathrm{Feb})$ & - & - \\
\hline SPI3 & 2000(Apr) & 2000(Jun) & - & - & 2008(Apr) & 2008(May) & - & - \\
\hline SPI1 & 2000(Mar) & 2000(Apr) & 2001(Apr) & 2001(May) & 2008(Mar) & 2008(Apr) & 2011(Dec) & 2012(Jan) \\
\hline
\end{tabular}




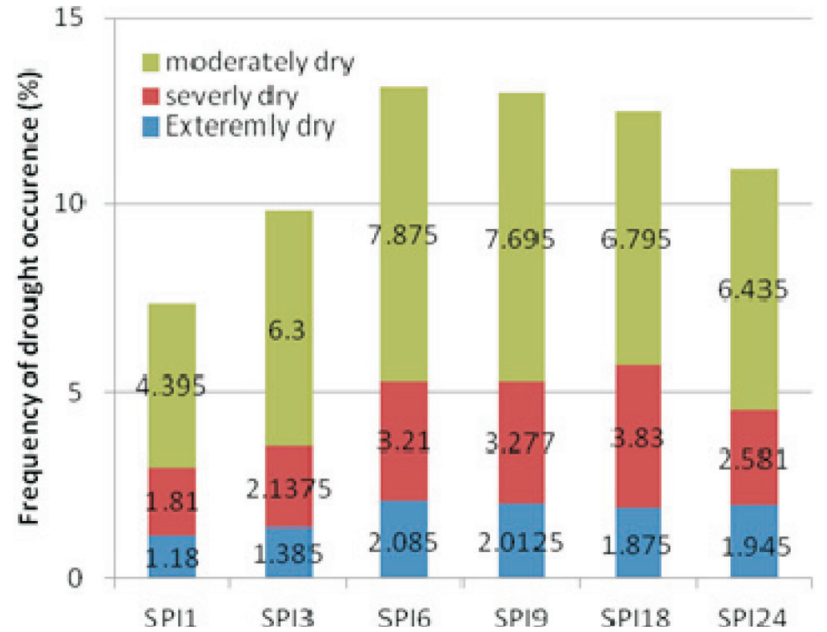

Figure 3 - Comparison of percentage of drought severity categories identified using SPI. central parts, while occurrence of drought frequency were $0-5$ times in the other parts of province during 30 years. So, it is clear that the probability of desertification and destruction in the central parts of province are more than other parts.

For better understanding of the changes in the situation of drought was used the spatial and the maps of drought for the period 1980-2012 were drawn (Fig. 6). It is clear that, the 1989 was started drought condition from the northwest and eastern parts of province until 1990 dry condition covered the whole of the study area, then the normal condition return in next year until 1994. Dry condition covered again the whole of province in 1995, 2000, 2008 and 2010, while the wet conditions were observed from 1991 to 1994 and 2001-2005 years.

A general result of drought patterns maps show that the northern and central parts of this province had experi-

Table 4 - Relative frequencies (\%) of different categories detected by six time-scale of SPI during 1980-2012.

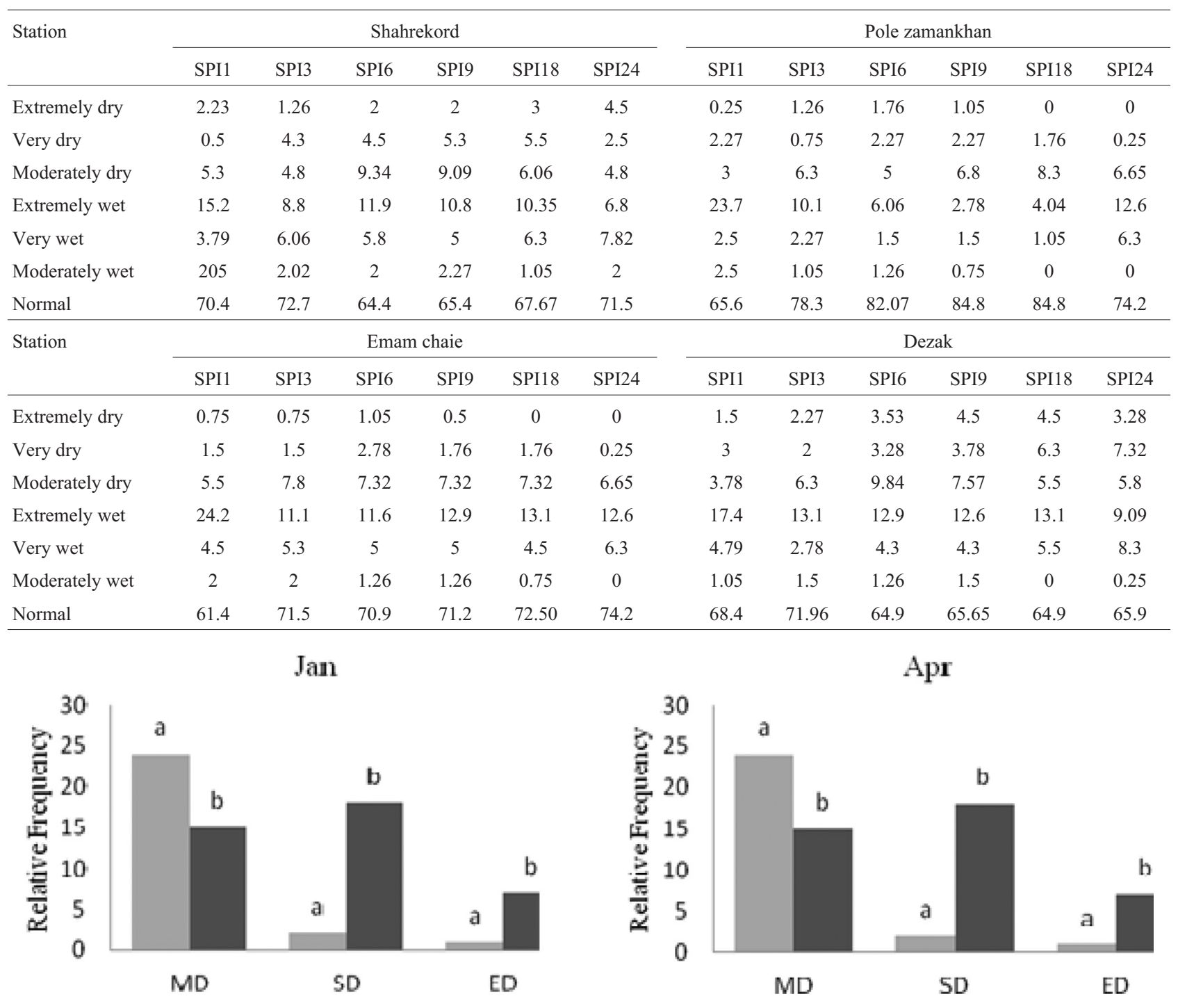

Figure 4 - Histograms for the drought frequency classes of the SPI1 (a: 1983-1998 and b: 1998-2013). 

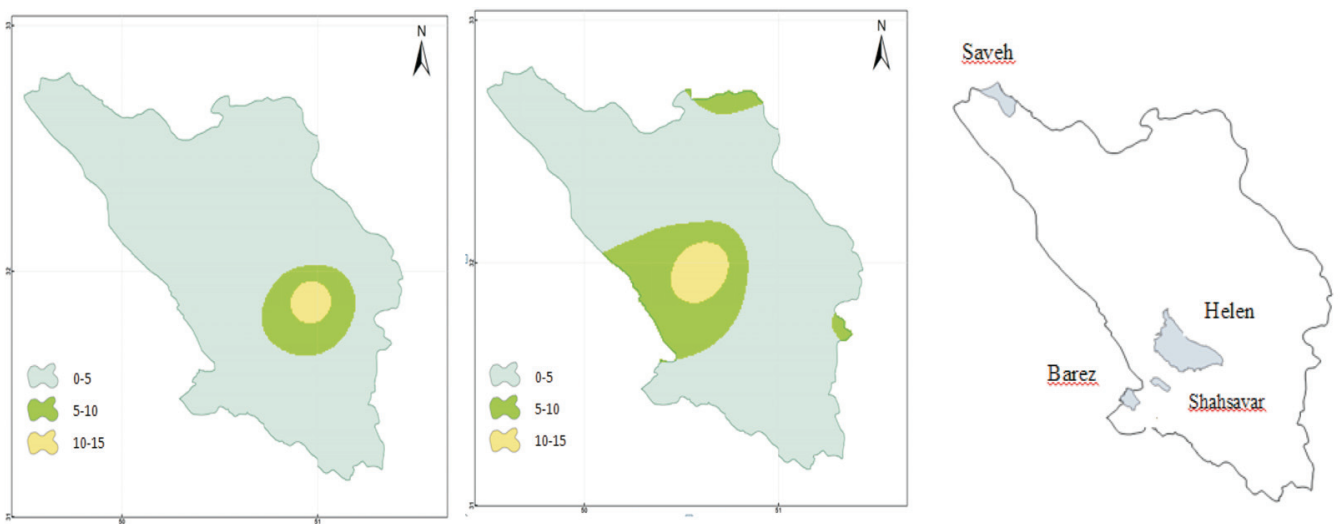

Figure 5 - The frequency of drought occurrence from 1983-1998 (the west), 1998-2013 (the east) and forest under oak decline in Chaharmal-Bakhtiyari province.

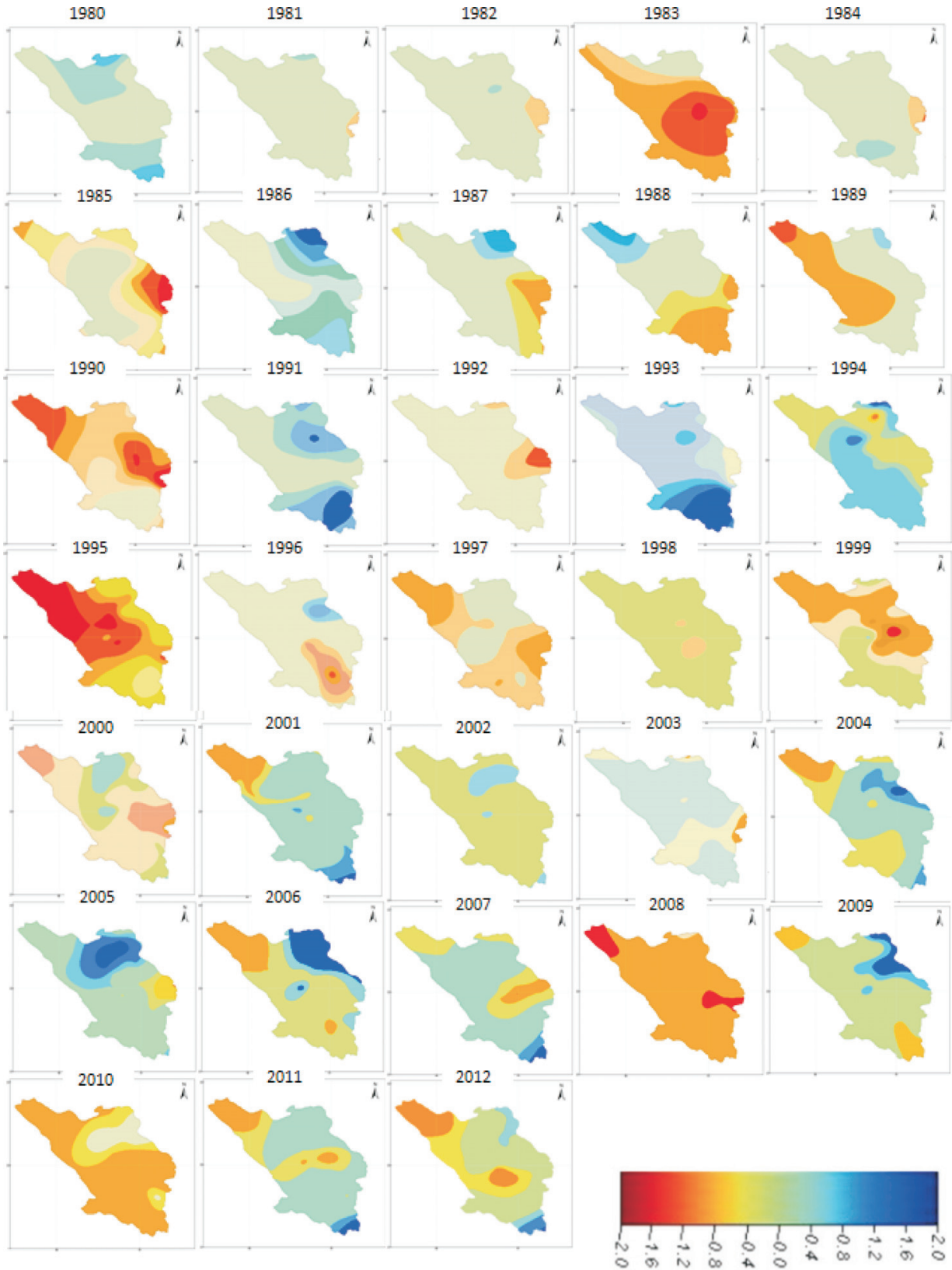

Figure 6 - Spatial distribution of SPI12 from 1980 to 2012. 
enced droughts more than other places, and these place have potential to destroy the lands.

\section{Conclusion}

In this paper, the main aim was the evaluation and monitoring of drought by SPI in different time scales for in the Chahrmal-Bakhtiyari Province in Iran. Duration, frequency and magnitude of drought have been studied. Totally, the results which are based on precipitation are important for decision makers and water management.

The study used 32 years (from 1980 to 2012) of monthly precipitation data. The SPI in different time scales were used to determine the onset and end of drought history in the study area. The results show that selection of different time scales can be based on management goals. The SPI at one time scale reflects short-term precipitation patterns, While the SP18, SPI12, SPI24 and SPI48 responds more slowly to changes in precipitation and gives longer duration of drought compared to SPI1, SPI3. Hayes et al. (1999), mentioned that SPI1 and SPI3 indicated a severe drought although only a low amount of precipitation was short in dry seasons, since SPI1 and SPI3 are nearly the same concepts as percentage anomaly.

The SPI 12 considers rainfall shortage for only 1 year, so, the large observed difference in index values occurred. Also, by identification of sensitivity region can be take appropriate management to prevent damage resulting of drought. A general result of drought patterns maps show that the northern and central parts of this province had experienced droughts more than other places, and these place have potential to destroy the lands. With consider that the forests have a vital role on decreasing of greenhouse gas in the world, so protections of them are important. While, oak forest where are located in Zagros areas suffer from oak decline without any known reason, which leads to destruction on recent decade. Studying the frequency of drought and distribution of forest under oak decline showed that the southwest parts of province are vulnerability to both of oak decline and drought frequency. So it maybe, drought be one of the main reasons of oak decline.

\section{References}

BYUN, H.R.; WILHITE, D.A. Daily quantification of drought severity and duration. Journal of Climate, v. 5, p. 1181-1201, 1996.

GUTTMANN, N.B. Comparing the palmer drought index and the standardized precipitation index. Journal of Water Resour., v. 34, p 113-121, 1998.
HAO, Z.; AGHAKOUCHAK, A. Multivariate standardized drought index: A multi-index parametric approach for drought analysis. Journal of Water Resour., v. 57, p. 12-18, 2013.

HAYES, M.J.; SVOBODA, M.D.; WILHITE, D.A.; VANYARKHO, O.V. Monitoring the 1996 drought using the Standardized Precipitation Index (SPI). Bulletin of the American Meteorological Society, v. 80, p. 429-438, 1999.

HAYES, M.; SVOBODA, M.; WALL, N.; WIDHALM, M. The Lincoln declaration on drought indices, Universal meteorological drought index recommended. Journal of Meteor Socity, v. 92, p. 485-488, 2011.

JAIN, K.; PANDEY. R.; JAIN, M.; BYUN, HR. Comparison of drought indices for appraisal of drought characteristics in the Ken river basin. Journal of Weather and Climate Extremes, v. 8, p. 1-11, 2015.

MCKEE, T.B.; DOESKEN, N.J.; KLEIST, J. The Relationship of drought frequency and duration to time scales. Conference on Applied Climatology, p. 17-22, 1993.

MO, K.C. Drought onset and recovery over the United States. Journal of Geophysic Resource, v.116, p. 201-216, 2011.

MORID, S.; SMAKHTIN, V.; MOGHADDASI, M. Comparison of seven meteorological indices for drought monitoring in Iran. Journal of Climatology, v. 26, p. 971-985, 2006.

PALMER, W.C. Meteorological drought, Research IN Department of Commerce Weather Bureau, n. 45, 1965.

PANDEY, R.P.; DASH, B.B.; MISHRA, S.K.; SINGH, R. Study of indices for drought characterization in KBK districts in Orissa. Journal of Hydrology, v. 22, p. 1895-1907, 2008.

PAULO, A.; PEREIRA, L. S. Drought concepts and characterization, Water International, v. 31, p. 37-49, 2006.

RIEBSAME, W.E.; CHANGNON, S.A.; KARL, T.R. Drought and natural resource management in the United States: impacts and implications of the 1987-1989 drought. Westview Press, p. 174, 1991.

ROUDIER, P.; MAHE, G. Study of water stress and droughts with indicators using daily data on the Bani River (Niger Basin, Mali). Journal of Climatology, v. 30, p. 1689-1705, 2010.

WILHITE, D.A. Drought and water crises. Science, Technology, and Management Issues. Taylor and Francis, p 406, 2005.

WILHITE, D.A.; GLANTZ, M.H. Understanding the drought phenomenon: The role of definitions. Water Intternational Journal, v. 10, p. 111-120, 1985.

WORLD METEOROLOGICAL ORGANIZATION (WMO). Drought Monitoring and Early Warning: Concepts, progress and future challenges. World Meteorological Organization, n. 1006, 2006.

WU, H.; HAYES, M.J.; WELSS, A.; HU, Q. An Evaluation the standardized precipitation index, the China-Z index and the statistical Z-Score. International Journal of Climatology, v. 21, p. $745-758,2001$

This is an Open Access article distributed under the terms of the Creative Commons Attribution Non-Commercial License which permits unrestricted non-commercial use, distribution, and reproduction in any medium provided the original work is properly cited. 